\title{
São as indicações geográficas um instrumento para o desenvolvimento dos territórios? Estudo de caso sobre duas experiências no estado do Rio Grande do Sul
}

\author{
Flávio Sacco dos Anjos' \\ Fernanda Novo da Silva ${ }^{2}$ \\ Nádia Velleda Caldas ${ }^{3}$ \\ Germano Ehlert Pollnow 4
}

\section{Resumo}

Neste artigo, analisa-se a questão relativa às indicações geográficas enquanto instrumento para o desenvolvimento dos territórios. Depois de realizar um resgate sobre o tema, oferece-se ao leitor a oportunidade de conhecer dois casos existentes no estado do Rio Grande do Sul (vinhos do Vale dos Vinhedos e carne do pampa gaúcho da campanha meridional). As duas experiências

I Doutor em Sociologia e Professor Associado III pela Universidade Federal de Pelotas (UFPel), Pelotas, Rio Grande do Sul, Brasil. É autor de artigos publicados nas revistas Journal of Rural Social Sciences (20 I I), Revista de Economia Agrícola (Impresso) (20l I), Investigaciones Geográficas (México) (20l0) e Agricultura Familiar en España (20/0), além de ser autor de capítulos dos liuros Desenvolvimento Territorial: Produção, Identidade e Consumo (ljui - RS) (20/2) e Sociologia: Conexões Pertinentes (Pelotas - RS) (20/2).E-mail: saccodosanjos@gmail.com.

2 Agrônoma, Mestre em Ciências e Doutoranda no Programa de Pós-Graduação em Sistemas de Produção Agricola Familiar pela Universidade Federal de Pelotas (UFPel), Pelotas, Rio Grande do Sul, Brasil. É autora de artigos publicados nas revistas Desenvolvimento Regional em debate (2012), Geografia (Rio Claro. Impresso) (2009), além de ser autora de um dos capítulos do liuro Os Desafios do Desenvolvimento: tendências e perspectivas para a economia gaúcha (Porto Alegre-RS) (2011).E-mail: agronanda@yahoo.com.br.

3 Socióloga, Doutora em Agronomia e Professora Adjunta I pela Universidade Federal de Pelotas (UFPel), Pelotas, Rio Grande do Sul, Brasil. É autora de artigos publicados em: Revista de Economia e Sociologia Rural (Impresso) (2012), Estudios Sociológicos (2011), Iberoamericana (Madrid) (2009), Raizes (UFPB) (2010), entre outras. E-mail: velleda.nadia@gmail.com.

4 Bolsista de Iniciação Científica do Conselho Nacional de Desenvolvimento Científico e Tecnológico Universidade Federal de Pelotas (UFPel), Pelotas, Rio Grande do Sul, Brasil. É autor de artigo publicado na revista Desenvolvimento Regional em debate (2012).E-mail: germanogp/3@gmail.com. 
guardam enormes diferenças. A conclusão a que chegam os autores é a de que o êxito dessas experiências é governado pela existência de capital social nos territórios e pela capacidade de organização dos atores sociais.

Palavras-chave: Indicações geográficas. Desenvolvimento territorial. Capital social.

\section{Introdução}

No último lustro, assiste-se ao surgimento de diversos trabalhos que aludem à dinâmica dos chamados "signos distintivos de mercado". Nesse contexto, sob a denominaçáo genérica de produtos de qualidade diferenciada, estariam incluídas as indicaçóes geográficas, mas também as especialidades regionais, os produtos oriundos da produçáo ecológica, orgânica ou da agricultura integrada, do comércio justo e solidário etc. No sul do Brasil, sáo igualmente conhecidos os apelos aos artigos ditos 'coloniais', os produtos da agricultura familiar e uma plêiade de iniciativas que recorrem aos mais distintos tipos de narrativas socioculturais que, em última instância, vão muito além de um simples rótulo ou etiqueta aderida à embalagem.

Em que medida esses dispositivos de diferenciaçáo representam um instrumento catalisador da inovaçáo no âmbito dos territórios? Sáo eles um meio através do qual é possível fomentar processos de cooperaçáo ou de coesáo social, e, simultaneamente, enfrentar os desafios do desenvolvimento, sobretudo no âmbito das pequenas localidades e áreas rurais?

Os dois casos que seráo aqui analisados exemplificam, graficamente, os contornos dessa discussão. Em linhas gerais, são essas as indagaçóes que inspiraram a elaboraçáo deste trabalho, que se divide, além dessa breve introduçáo, em quatro outras partes. A primeira delas é dedicada a analisar as grandes orientaçóes teóricas que, atualmente, galvanizam a atenção dos estudiosos sobre aspectos ligados ao desenvolvimento rural e/ou territorial. Trata-se de explorar o universo de possibilidades que se abrem para dar conta das grandes questóes expostas anteriormente. $\mathrm{Na}$ segunda seção, discute-se o tema das indicaçóes geográficas (doravante IGs) no Brasil, com destaque para a evoluçáo recente desses dispositivos de diferenciaçáo e suas distinçóes em relação a países europeus onde existe um marco legal e institucional consolidado. A terceira seção é dedicada a realizar uma aproximação a duas experiências de indicaçóes geográficas existentes no estado do Rio Grande do Sul. São dois casos referenciais de que nos servimos para mostrar as diversas contradiçóes que 
obram sob a superfície quando se examina, com certo grau de profundidade, o potencial das indicaçóes geográficas para o desenvolvimento dos territórios e/ou para a impulsáo de processos de inovaçáo e cooperaçáo em torno da valorizaçáo de produtos agroalimentares. A quarta e última seçáo deste artigo reúne as conclusóes deste estudo.

\section{A abordagem territorial e o capital social dos territórios}

Há, pelo menos, duas grandes vertentes do pensamento social debruçadas sobre o exame do que, até entáo, se veio denominar 'desenvolvimento rural'. Seria absolutamente impensável analisar, no espaço de que aqui dispomos, todos os meandros de uma discussáo que permanece absolutamente aberta. A primeira das grandes vertentes se identifica com o que se conhece como abordagem territorial do desenvolvimento. A segunda delas tem a ver com a ideia de capital social, uma noção consagrada atualmente nos meios acadêmicos no centro dessa discussáo.

\section{I A abordagem territorial do desenvolvimento}

Há, no limite, pelo menos três grandes vícios de origem na concepção que convencionalmente guiou a atuação do Estado brasileiro no âmbito do desenvolvimento rural. O primeiro deles recai no 'viés setorial', que reduz toda a discussáo sobre os desafios do desenvolvimento ao marco estrito do apoio a cadeias produtivas ou a setores específicos da atividade agropecuária, alimentando a ilusáo de que todo esse esforço pudesse se espraiar sobre o tecido social das áreas rurais e das pequenas localidades.

O segundo vício de origem, parafraseando Favareto (2007, p. 14), é o viés do combate à pobreza rural, cuja natureza reflete os anseios do Estado brasileiro em ampliar as fontes de legitimidade de sua atuação, vinculando-a ao âmbito estrito do combate a essa mazela social que acomete os mais distintos rincóes da geografia nacional. Por mais meritória que seja essa cruzada, náo cabe dúvida de que o enfrentamento aos desafios do desenvolvimento requer muito mais do que isso, sobretudo quando se alude ao fomento de processos de inovação, concertação social, formação de alianças estratégicas e de consolidaçáo de pactos territoriais de longo prazo para o combate às desigualdades sócio-espaciais. 
Já o terceiro vício de origem tem a ver com as transformaçóes decorrentes da nova Constituiçáo Brasileira (1988) e das mudanças no ordenamento político e institucional brasileiro que convergiram para a transferência de diversas competências da União para a órbita dos municípios. Mas, se os problemas atinentes à municipalização já sáo, por si sós, bastante conhecidos, ainda mais graves são os efeitos atinentes ao que se veio a chamar de "prefeiturizaçáo" (ANJOS; CALDAS, 2007, p. 665), notadamente a velha tendência de concentrar, no poder público municipal, a solução para os problemas locais, numa eterna disputa por recursos, invariavelmente escassos, com outras prefeituras da regiáo, em lugar de estabelecer pactos e fomentar sinergias em torno a objetivos mais amplos à escala territorial.

O que aqui se quer afirmar, em última análise, é que a abordagem territorial, que serve de fonte inspiradora para as propostas de intervençáo das agências nacionais e internacionais de desenvolvimento (especialmente a FAO, IICA, CEPAL) ${ }^{5}$, surge, entre outros aspectos, como um esforço de ultrapassar os limites impostos por esses três vícios de origem da atuação estatal e dos órgáos de cooperaçáo e fomento. Essa tem sido a tônica de alguns estudos (VEIGA, 2000; ABRAMOVAY, 2003; FAVARETO, 2007; ANJOS, 2003) realizados recentemente no Brasil, os quais, em linhas gerais, reivindicam um novo olhar para os espaços rurais e para as regióes náo densamente urbanizadas.

Todavia, como advertiu Favareto, longe estamos de operar essa "mudança de paradigma" no sentido de alterar um padráo ${ }^{6}$ que segue sendo absolutamente dominante, de ultrapassar as fronteiras da simples retórica e que sirva para reformular o papel das instituiçóes que militam nesse campo. Convergimos com esse entendimento, sobretudo quando o citado autor afirma que "a introduçáo do adjetivo territorial no repertório das organizaçóes não governamentais, da burocracia estatal e dos movimentos sociais é marcada pelos limites de uma incorporaçáo 'por adição' [...] e náo como um sinal de mudança institucional.” (FAVARETO, 2010, p. 314; destaque do autor).

5 A FAO (Food and agriculture Organization, ligada à Organização das Nações Unidas), o IICA (Instituto Interamericano para o Desenvolvimento Agrícola) e a CEPAL (Comissão Econômica da ONU para a Cooperação Agricola) são as principais organizações identificadas com o desenvolvimento rural.

6 Favareto (2010, p. 310), em suas acertadas críticas, menciona dois documentos referenciais (Relatório do Banco Mundial de 2004, intitulado Beyond The City, e o texto Política de Desarrollo Rural, elaborado em 2005 pelo Banco Interamericano de Desenvolvimento), em que são flagrantes essas contradições e ambiguidades. Segundo suas próprias palauras, "[...] tenta se aplicar um viés territorial, mas nas considerações, nos instrumentos e nas orientações enunciadas o viés é claramente produtivista e setorial.". 
Não é preciso muito esforço para mostrar quão fortes são as amarras que nos prendem ao que Hervieu (1996, p. 105) magistralmente definiu como "fundamentalismo agrário", ao comentar a trajetória da política agrária dos países que atualmente integram a União Europeia, sobretudo com respeito às dificuldades de reorientar os instrumentos públicos de intervençáo, superando os vícios de origem que elencamos no parágrafo precedente. A preocupação em torno do despovoamento das áreas rurais e do destino das regióes deprimidas serviu de base para o surgimento de um novo marco de intervençáo nos países pertencentes ao velho continente, como é precisamente o caso do LEADER ${ }^{7}$, em suas sucessivas ediçóes, e de outros programas como PRODER ${ }^{8}$.

O que estes estudos reafirmam, de modo peremptório, é que o território pressupóe interação social, além de ser fonte de conhecimento, "de geração e difusão de inovaçáo" (ORTEGA; JEZIORNY, 2011, p. 113). Não pode, portanto, ser definido pelo estoque de recursos materiais existentes em seu interior, mas sim pela maneira como os atores sociais e as instituiçóes se organizam a partir de modelos mentais partilhados. A necessidade de cooperar e de construir pactos é cada vez maior em meio a um contexto de globalização, no qual as novas tecnologias de informaçãa, comunicação e transporte repercutem, cada vez mais, sobre todos os territórios e âmbitos da vida social, produzindo a anulaçáo do espaço pelo tempo, acirrando a competitividade e a exposiçáo do tecido socioprodutivo ao sabor das relaçóes de mercado.

\subsection{O capital social dos territórios}

Que razóes conspiram para o fato de alguns territórios rurais converterem-se em terreno fértil para fazer aflorar a inovação, os processos de cooperaçáo, a atraçáo de novos investimentos e respirar dinamismo nas mais distintas esferas da atividade produtiva, enquanto outros permanecem mergulhados no ostracismo, mesmo nos casos em que há um importante estoque de ativos e de recursos produtivos?

7 LEADER é o nome dado às sucessivas iniciativas de desenvolvimento rural da União Europeia. A sigla corresponde a Liaisons entre activités de Development de L'Economie Rural.

8 PRODER é o Programa Operativo de Desenvolvimento e Diversificação Econômica de Zonas Rurais. É um programa nacional de desenvolvimento rural desenhado e aplicado em cada país europeu, co-financiado pela União Europeia, cuja finalidade é impulsionar o desenvolvimento das zonas rurais desfavorecidas através da diversificação das atividades econômicas. 
A ideia de "capital social" surge como um intento de resposta a esses e outros enigmas que afetam o desenvolvimento dos territórios. Tal como afirmou Estrada (2006, p. 106), ao final dos anos 1980, sociólogos, cientistas políticos e alguns economistas que trabalhavam no campo da sociologia econômica, os quais buscavam combinar enfoques macro e micro sociológicos para explicar o comportamento econômico dos indivíduos, consideravam que o capital físico (terra e capital) e o capital humano (nível de escolaridade) eram insuficientes para explicar as diferenças nos processos de desenvolvimento entre comunidades. Admitiam, portanto, que havia outros fatores (não econômicos) de grande importância explicativa, os quais náo eram levados em conta nessas análises. Incorporaram, assim, um terceiro fator que se veio denominar "capital social", recuperando uma noçáo que estava sendo utilizada no campo da sociologia desde o final dos anos 1960 em diversas áreas da investigação.

Quando se alude ao capital social dos territórios, busca-se, no limite, romper, como advertiu Abramovay (2003, p. 86), citando Coleman (1990), com um dos mitos fundadores da civilizaçáo moderna, no sentido de entender que a sociedade é um conjunto de indivíduos agindo isoladamente para atingir objetivos a que chegam independentemente uns dos outros. Além disso

A noção de capital social permite ver que os indivíduos não agem independentemente, que seus objetivos não são estabelecidos de maneira isolada e seu comportamento nem sempre é egoísta. Neste sentido, as estruturas sociais devem ser vistas como recursos, como um ativo de capital que os indivíduos podem dispor (ABRAMOVAY, 2003, p. 86).

A importância dessa ferramenta interpretativa ganha uma dimensão considerável a partir dos estudos de Putnam, surgidos ao longo dos anos 1990, cujo foco esteve dirigido a examinar as diferenças de desempenho econômico e institucional entre as regióes italianas. Suas investigaçóes mostram que as zonas setentrionais da Itália ostentam padróes e sistemas dinâmicos de engajamento cívico, em que os cidadãos são atuantes e imbuídos de espírito público e as relaçóes políticas sáo igualitárias. Uma regiáo em que a estrutura social descansa, firmemente, sobre um sentimento de confiança e colaboração. No extremo oposto, nas zonas que conformam a Itália meridional, a situaçáo é diametralmente oposta. A vida social se baseia no isolamento, na falta de integração, em meio a uma cultura regida pela desconfiança, pela quase total ausência de valores cívicos, bem como por uma estrutura política verticalmente estruturada. 
O ponto de vista de Putnam se aproxima ao de outro autor clássico da nova sociologia econômica - Mark Granovetter. Em seus trabalhos (1985; 1990), este autor insiste no fato de que a ação econômica é socialmente situada, que os indivíduos náo agem de maneira autônoma e que suas açóes estáo imbricadas em sistemas concretos e contínuos de relaçóes sociais que conformam redes, traduzidas num termo - embeddedness ${ }^{9}$ - já consagrado no jargáo acadêmico brasileiro e mundial. Granovetter (1990) estabelece dois tipos de imbricaçáo: o relacional e o estrutural. O primeiro deles diz respeito às relaçóes pessoais, ou seja, às relaçóes mais próximas dos indivíduos (família, amigos etc.), também definidas como "laços fortes". Já o segundo tipo compreende as relaçóes mais afastadas, às quais o indivíduo tem acesso graças aos seus laços fortes, mas que o colocam em contato, através de "laços fracos", com universos sociais distintos.

Considerado como um dos fundadores da nova sociologia econômica, Granovetter (1973) argumenta, em um trabalho que se tornou célebre (The strength of weak ties), que a força está justamente nos laços fracos porque sáo eles os responsáveis por expandir os horizontes, abrindo espaço para os processos de inovação e de aprendizagem no âmbito dos territórios. Num país multicultural e de dimensóes continentais, como é o Brasil, marcado por diferenças abissais entre as grandes regióes e seus territórios, do ponto de vista do desenvolvimento humano e de outros indicadores, náo causa estranheza a rapidez com que o capital social converteu-se numa espécie de farol acionado para iluminar todo um debate, que, no limite, extrapola os cânones estritos da perspectiva acadêmica.

O capital social, como vaticinou Abramovay (2003, p. 87), corresponde ao ethos de uma certa sociedade e, no nosso entendimento, a uma identidade moldada a partir de um conjunto de valores compartilhados, os quais náo são transferíveis de um contexto para outro. Isso é crucial, sobretudo quando pensamos em valores simbólicos, a exemplo da disposiçáo para a cooperaçáo em torno da criaçáo de um novo sujeito coletivo que náo pode estar restrito a uma empresa, a um setor ou cadeia produtiva, mas sim a uma capacidade de

9 Como explica Machado (2010), Karl Polany, em sua obra seminal (A grande transformação: as origens de nossa época), é quase consensualmente considerado como o pai do conceito em tela, traduzido para o português como incrustação ou também enraizamento, mostrando que as ações econômicas dos individuos estão sempre inseridas em redes de relações sociais. 
articulação que faça aflorar as forças produtivas de um território em torno de uma determinada ideia-guia. Seria precisamente o caso da construçáo de uma indicaçáo geográfica? Antes de entrar, propriamente, no cerne dessa discussáo, convém realizarmos uma primeira aproximaçáo a esse tema, relacionando-o ao Brasil.

\section{As indicações geográficas no Brasil}

O marco legal das IGs do Brasil (Lei 9279 de 14/05/1996) é bastante recente e contempla somente duas figuras de proteção, quais sejam, a Indicação de Procedência (IP) e a Denominaçáo de Origem (DO). A IP se refere ao nome geográfico do país, cidade, regiáo ou localidade de seu território, a qual se tornou conhecida como centro de extração, produçáo ou fabrico de um determinado produto, ou pela prestaçáo de um determinado serviço. A DO, por seu turno, indica o nome geográfico de um país, cidade, regiáo ou localidade de um território e designa um produto ou serviço cujas qualidades se devem exclusiva ou essencialmente ao meio geográfico, incluindo os fatores naturais e humanos.

A distinçáo entre ambas as figuras está no fato de que, no caso da IP, o relevante é a notoriedade associada à qualidade que alcançou um determinado produto ou serviço, ao passo que, no caso da DO, a excelência de um ou de outro deve estar ancorada, obrigatoriamente, nos aspectos físicos (solo, água, clima), humanos e culturais do meio onde houve o processo de obtenção ou produçáo. Tanto a IP quanto a DO devem ter seus respectivos registros no Instituto Nacional de Propriedade Industrial (INPI).

Merece destaque o fato de que, até 2010, havia apenas seis (6) Indicaçóes Geográficas concedidas pelo INPI. Surgida em 2002, a IP para os vinhos finos e espumantes do Vale dos Vinhedos, sobre a qual trataremos com maior profundidade na próxima seçáo, corresponde à primeira delas, seguida do café do Cerrado (2005), da carne bovina e derivados do Pampa Gaúcho da Campanha Meridional (2006), da cachaça de Paraty (2007) e do couro curtido do Vale dos Sinos (2009). Não obstante, os dados da Figura 1 não deixam dúvidas acerca do vertiginoso incremento no número de IGs brasileiras, o qual foi multiplicado 4,7 vezes no espaço de tempo correspondente aos últimos dois anos, e que, até o momento de elaboração deste trabalho, compreendia 21 IPs e sete DOs (28 IGs no total). 
Mas, se no caso da Europa, esse tipo de dispositivo de diferenciaçáo, normatizado, atualmente, pelos Regulamentos CE 2081/92 e 2082/92, contempla, exclusivamente, produtos agroalimentares, no caso brasileiro, há uma plêiade de artigos, incluindo calçados, pedras, mármores, produtos e serviços, que, em última análise, não guardam relação alguma com o mundo da alimentaçáo e/ou da produçáo agropecuária.

Esse dado nos mostra que, ao pensar em IG, no Brasil e no velho continente, podemos estar referindo-nos a coisas absolutamente distintas. No âmbito europeu, para que um artigo leve a indicaçáo DOP (Denominação de Origem Protegida), todas as fases de produçáo devem realizar-se dentro de uma zona delimitada, sendo que as características do produto dependem exclusiva, ou essencialmente, de sua origem geográfica. Já no caso da IGP (Indicaçáo Geográfica Protegida), ao menos uma das citadas fases de elaboraçáo deve realizar-se dentro de um determinado território, sendo que o vínculo com o mesmo deve estar justificado pelo fato de estar relacionado a uma qualidade específica, reputaçáo ou outra característica do produto. Outro aspecto que merece destaque sobre o quadro brasileiro é a distribuição dessas figuras de proteçáo segundo as unidades federativas. Nesse sentido, nada menos que seis delas estáo no Rio Grande do Sul (uma DO e cinco IPs), seis, em Minas Gerais (todas IPs), quatro, no Rio de Janeiro (três DOs e uma IP), três, no Espírito Santo (todas IPs) e, em menor medida, nos demais estados do país.

Figura I - Evolução das Indicações Geográficas (Indicações de Procedência e Denominações de Origem) entre os anos 2002 e 2012.

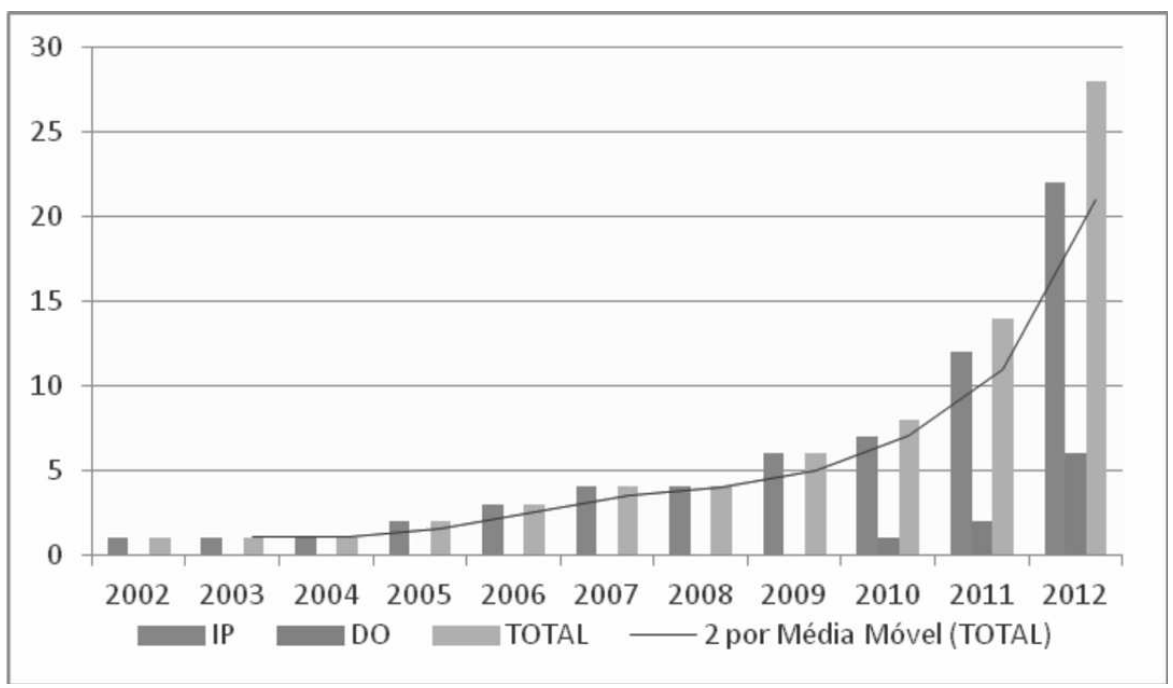

Fonte: elaboração dos autores a partir dos dados do MDIC/INPI. 


\section{Indicações geográficas e desenvolvimento territorial: entre mitos e realidades}

Nossa reflexáo, que explora as interfaces entre indicaçóes de geográficas e desenvolvimento territorial, descansa sobre o exame de duas experiências referenciais existentes no Rio Grande do Sul (Figura 2). O material reunido em 33 entrevistas realizadas entre os anos 2008 e 2012, com diferentes atores sociais (representantes de empresas, de Conselhos Reguladores, associaçóes de produtores, extensionistas rurais, agricultores etc.), mediante roteiro prévio de perguntas, foi submetido à análise de conteúdo, elegendo como categorias de análise temas como desenvolvimento, identidade e percepçáo do processo de construção social da qualidade, através da ótica dos próprios protagonistas.

As duas indicaçóes de procedência respondem ao apelo da diferenciaçáo sob um cenário cada vez mais competitivo. Náo obstante, como a seguir veremos, guardam enormes diferenças do ponto de vista dos arranjos institucionais e do capital social correspondente a estes dois territórios gaúchos.

Figura 2 - Mapa ilustrativo dos municípios que integram as Indicações Geográficas "Vale dos Vinhedos” (IPVV) e "Carne do Pampa Gaúcho da Campanha Meridional” (IPCPG).

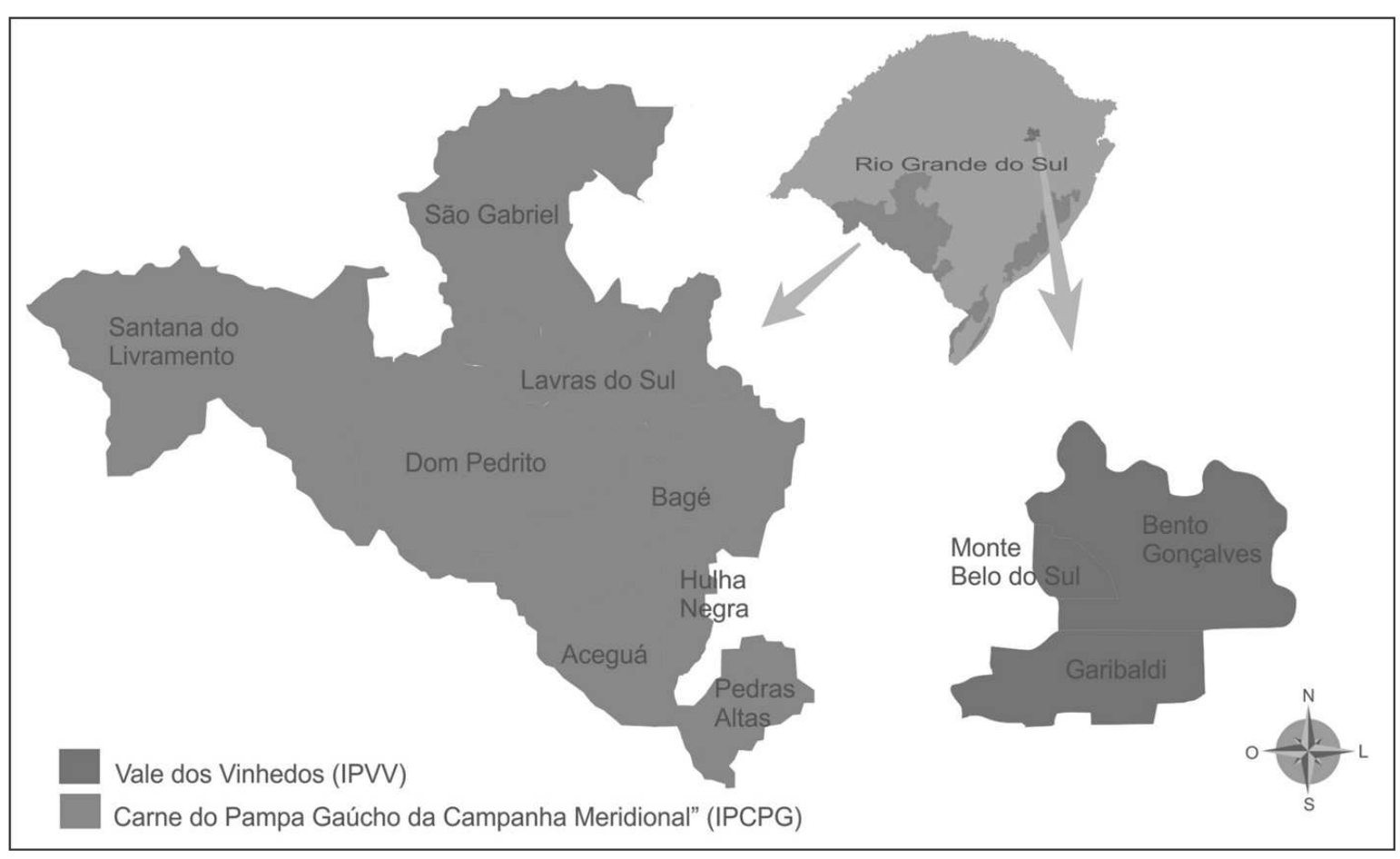

Fonte: elaboração dos autores (2012). 


\section{I Vinhos e espumantes do Vale dos Vinhedos}

O processo de colonizaçáo, levado a cabo no Rio Grande do Sul durante a primeira e a segunda metade do século XIX, exerceu enorme influência na conformaçáo atual dessa unidade federativa. Nesse sentido, importa destacar dois grandes efeitos desse processo, quais sejam, o de contribuir para a constituição de um dos mais importantes setores da agricultura familiar nacional e, por outra parte, o de assentar as bases para consolidar a indústria regional.

Tais efeitos estiveram estreitamente ligados ao protagonismo exercido pelos colonos procedentes da Europa (alemães, italianos, poloneses). Eles imprimiram à sociedade gaúcha um ethos singular (GAIGER, 1994; TEDESCO, 1999) que expressa os traços típicos do campesinato centro-europeu, principalmente seu dinamismo para a diversificação das atividades. Os analistas coincidem no entendimento de que as raízes da industrialização das zonas setentrionais desse Estado encontram-se, precisamente, associadas ao florescimento dessa "agricultura colonial" e ao processo de acumulaçáo de riqueza daí resultante, fenômeno para o qual foi muito importante o conhecimento técnico desses imigrantes.

Para os objetivos do presente artigo, importa destacar uma outra faceta deste cenário e que se associa à trajetória da imigraçáo italiana numa regiáo precisa desse Estado, qual seja, a chamada "Serra Gaúcha", conhecida como um importante destino turístico do Brasil meridional, onde se produz, atualmente, $90 \%$ da produção nacional de vinho. E é precisamente no interior dessa regiáo que se encontra a primeira experiência de indicaçáo geográfica do Brasil.

Até o início do século XX, o vinho era produzido com o fito de atender, fundamentalmente, ao consumo próprio das famílias, utilizando-se, para tanto, variedades rústicas de uva. Mas, a partir das décadas de 1970 e 1980, se ingressa numa outra etapa da vitivinicultura, com o aporte de capital internacional e a busca de aperfeiçoamento nos sistemas de produçáo, processo este impulsionado pela ampliaçáo do mercado interno, cada vez mais aberto ao consumo de vinhos de melhor qualidade. Nessa época, o Brasil adota uma política de incremento da qualidade centrada nos chamados vinhos varietais. Todavia, como afirma Tonietto (2006, p. 156), são vinhos cujo elemento de destaque não é a região produtora, mas a variedade da uva usada em sua elaboração. 
O período subsequente coincide com uma série de mudanças, entre as quais figuram a criação do Mercosul e os efeitos que engendram o setor vitivinícola nacional em face do ingresso dos vinhos procedentes do Chile e da Argentina, que entram em nosso país sob condiçóes tarifárias, as quais promovem uma feroz competência com o produto nacional. É justamente no rastro dessas questóes que se deve entender não somente a criação da Associação dos Produtores de Vinhos Finos do Vale dos Vinhedos (Aprovale), mas um conjunto de iniciativas centradas no objetivo de demonstrar o efeito terroir dessa regiáo sobre os vinhos elaborados.

Desse modo, o Brasil ingressa, como afirma Tonietto (2006, p. 158), na produção dos vinhos de "quarta geração", que devem afirmar a identidade e qualidade do produto nacional, seja no plano do mercado interno, em que se enfrenta a aludida competência do artigo importado, seja no plano do leque de oportunidades que brindam os mercados internacionais.

A estratégia adotada culminou na aparição da Indicaçáo de Procedência em 2002, através da qual se procede à adoção de critérios de delimitaçáo geográfica e criação de um Conselho Regulador. Essa IP abarca uma superfície de $81,23 \mathrm{~km}^{2}$ e se distribui por três municípios (Bento Gonçalves, Garibaldi e Monte Belo do Sul). Os produtos protegidos sáo os vinhos tintos, brancos e espumantes, havendo um conjunto de rigorosos procedimentos que devem ser cumpridos para que os mesmos levem a etiqueta "Vale dos Vinhedos". A Aprovale congrega, atualmente, 31 vinícolas, além de 28 associados, que incluem hotéis, restaurantes, queijarias, pousadas e outras empresas.

A principal agência de pesquisa agrícola do Brasil (Embrapa) desempenhou um papel de destaque nesse processo, por meio do qual se buscava uma saída à crise produzida pelos vinhos estrangeiros. $\mathrm{O}$ principal agente articulador dessa iniciativa menciona esse fator como decisivo para induzir ao processo que culminou na formaçáo da Aprovale, num primeiro momento, e num segundo momento, na criação da IP. Segundo suas próprias palavras:

[o] Vale dos Vinhedos é uma carta de apresentação, é um diferencial, contatar com [sic] o pessoal do Vale dos Vinhedos é um pessoal diferenciado [sic] [...] Isso aí ajuda a enfrentar esse mercado muito complicado, muito complicado. É um fator que tem ajudado, e essa é a ideia. Quando a gente começou a construir as indicações geográficas, aqui no Brasil, pra vinhos, se sabia que o mercado ia abrir porque tem 
gente muito boa nesse mundão afora, as regiões são cada vez melhores, investindo

[...] Sem qualidade não se consegue nada. ${ }^{10}$

Tal experiência gerou importantes efeitos tanto interna quanto externamente à regiáo. No primeiro caso, há que se mencionar os benefícios sobre os processos de produçáo vitivinícola, que trouxeram consigo a incorporaçáo da rastreabilidade e de diversos mecanismos de controle da qualidade da uva e do vinho, e também a perspectiva do fortalecimento de uma identidade regional calcada na alusáo à história dos pioneiros, que se reflete no encanto de paisagens que incluem caminhos rurais, casarios de pedra e velhas cantinas, em meio a um cenário que lembra o distante Vêneto, a Lombardia ou o Piemonte italiano.

O êxito verificado na iniciativa do Vale dos Vinhedos induziu, nessa regiáo, à criação de outras associaçóes de produtores, imbuídas do mesmo objetivo, como é o caso da Aprobelo (Associaçáo dos Vitivinicultores de Monte Belo do Sul), Afavin (Associação Farroupilhense de Vinicultores), Apromontes (Associaçáo de Produtores dos Vinhos dos Altos Montes) e Asprovinho (Associaçáo dos Produtores de Vinhos de Montanha). Tais associações encontram-se articuladas em torno de um ambicioso projeto nacional intitulado" Wines of Brazil, cuja meta é dar a conhecer, internacionalmente, a qualidade e a singularidade dos vinhos do país, qualidades evidentes no alto nível de protagonismo dessa zona situada no interior da Serra Gaúcha ${ }^{12}$. Se nos fixamos no âmbito externo, há que se afirmar que essa experiência contribuiu para impulsionar o florescimento de outras experiências de IG no Rio Grande do Sul (Carne do Pampa Meridional Gaúcho, Arroz do Litoral Norte e Couros do Vale dos Sinos) e em outras regióes do país, como é o caso da Cachaça do Brasil e do Café do Cerrado, tal como vimos na seção precedente.

Entrementes, o Vale dos Vinhedos enfrenta algumas dificuldades relacionadas com o esforço de conciliar os distintos interesses implicados (públicos e privados) e de sedimentar as bases para uma estratégia territorial de longo prazo.

10 Entrevista concedida no dia 28 de abril de 2008 no município de Bento Gonçalves, RS. Omitimos quaisquer informações que pudessem revelar os nomes das pessoas entrevistadas.

$1 /$ Ver, a esse propósito, http://www.winesofbrasil.com/Default_pt.aspx.

12 Entre as conquistas da Aprovale, há que se mencionar o reconhecimento do Vale dos Vinhedos, em 2007, pela União Europeia, o que permitiu a exportação, nesse mesmo ano, de 435 mil litros de vinho, uma modesta quantidade que corresponde a 35\% da produção certificada (NIEDERLE, 2009, p. 12), mas interessante para acalentar o sonho de abertura de novos mercados. 
Um dos grandes problemas resulta do protagonismo excessivo das grandes vinícolas, em virtude do considerável peso econômico e político que lhes corresponde no plano local e regional. O contato com os atores que interagem, nesse cenário, detectou alguns discursos que se chocam, frontalmente, com as virtuosidades do "Vale dos Vinhedos".

Referimo-nos, especialmente, às organizaçóes não governamentais ligadas à produçáo ecológica que consideram que essa iniciativa reproduz os mesmos mecanismos de extração do sobretrabalho dos produtores familiares de uva. Além disso, argumentam que há um claro desprestígio com relação à produçáo vitivinícola gerada através de variedades rústicas, como no caso da cultivar Isabel: apesar da produçáo de um vinho considerado de qualidade inferior, o sistema de produção que lhe corresponde demanda uma carga infinitamente menor de agrotóxicos, comparativamente ao das uvas finas ou viníferas ${ }^{13}$.

Ainda assim, o balanço ${ }^{14}$ da iniciativa da IPVV é positivo, particularmente por favorecer a emergência de uma série de empreendimentos cujo atrativo essencial reside no chamado "enoturismo". Nesse mesmo espaço (Serra Gaúcha), e sob o mesmo tipo de apelo - a cultura italiana e os encantos do seu entorno natural e paisagístico -, surgiram outros processos de valorizaçáo da identidade regional, como é o caso dos "Caminhos de Pedra". A identidade étnica ítalo-brasileira, forjada na saga dos imigrantes, ergue-se a partir da exaltaçáo de certos traços (religiosidade, campesinidade, gastronomia ou ética do trabalho) que, conjuntamente, são decisivos na ativação de um imaginário social claramente identificável.

A arquitetura típica dos casaróes de pedra e a beleza dos caminhos rurais se conectam de forma harmônica com a atmosfera mágica do mundo do vinho. É um processo recente que exigiu uma série de medidas, náo somente orientadas a recuperar e preservar o patrimônio material na montagem de rotas turísticas, mas, especialmente, em prol do resgate de certos bens imateriais

13 Guardadas as devidas proporções, trata-se de um enfrentamento similar ao verificado no caso espanhol em relação ao azeite de oliva e que coloca, em trincheiras opostas, dois grandes grupos. De um lado, os produtores ligados às denominações de origem e, de outro, os que se identificam como produtores do azeite ecológico. Por mais segmentado que seja o mercado de azeites de qualidade, não resta dúvida de que existe uma acirrada disputa entre duas concepções que defendem a qualidade e a diferenciação de seus produtos.

14 Um dos grandes logros associados à iniciativa "Vale dos Vinhedos" consiste em mostrar a importância de frear o avanço do processo de urbanização sobre as áreas rurais, particularmente no município de Bento Gonçalves, através da criação de condominios horizontais e loteamentos. 
(idioma, folclore, arte e habilidades manuais etc.) e profissionalizaçáo dos atores locais (CERDAN; SOUZA; FLORES, 2009, p. 307).

Mas, não há dúvida de que existem importantes diferenças entre a iniciativa do Vale dos Vinhedos e a dos Caminhos de Pedra. Assim, enquanto a primeira revela uma estratégia típica de agregaçáo de valor a uma cadeia de produto (vinhos e espumantes), a segunda representa uma estratégia típica de "cesta de bens", muito mais vinculada ao desenvolvimento integral do território. Acampora e Fonte (2007, p. 194) destacam que a estratégia de cadeia de valor está centrada em enaltecer um produto específico, portador de uma identidade cultural que lhe permite viajar a mercados distantes sem romper os vínculos com suas origens. Já no caso da estratégia "cesta de bens", trata-se de valorizar a identidade territorial, não por meio de um único produto, mas de um conjunto de ativos, dentro do qual um dos "marcadores de identidade" pode ser o grande protagonista, como é precisamente o caso do vinho.

Assim, enquanto no caso da primeira via se privilegiam, claramente, os vínculos verticais, na segunda, a primazia recai sobre os vínculos horizontais entre os atores envolvidos. Contudo, é importante destacar que as duas estratégias podem conviver, sendo perfeitamente compatíveis, convergentes e/ou complementares, se tivermos em mente que o vinho náo somente representa a ideia de um artigo tradicional, com toda carga de subjetividade, mas, sobretudo, cristaliza as características singulares do território e a herança cultural que persistem dentro daquela peculiar regiáo do país.

Encontramo-nos diante de duas experiências que surgiram muito mais como resultado da iniciativa dos próprios sujeitos envolvidos nesses processos do que propriamente por força da atuação do poder público. $\mathrm{O}$ conhecido empreendedorismo dos descendentes de italianos, a que anteriormente nos referimos, ergue-se como a força essencial que impulsionou tais iniciativas. Esse tipo de atributo também está presente no caso europeu, mas não se pode desconsiderar a existência de um ambiente institucional (ABRAMOVAY, 2006) que conspirou fortemente em seu favor, especialmente a partir do advento das Iniciativas LEADER e PRODER em suas sucessivas ediçóes.

\section{I.I O Capital social do Vale dos Vinhedos}

No livro recente publicado por Ortega e Jeziorny (2011), dedicado a estudar a experiência relativa à IPVV, os autores concluem (p. 149) que as 
indicaçóes geográficas e o território "[...] formam uma espécie de simbiose, pois não existe indicação geográfica sem o território, ao passo em que o próprio território pode se desenvolver por meio da construção de uma indicação geográfica."

Coincidimos, parcialmente, com essas premissas, e não foi por outro motivo que especial atenção foi dada, neste trabalho, à abordagem territorial do desenvolvimento. Não obstante, nossa ressalva recai no entendimento de que a realidade, náo raras vezes, evidencia a existência não de um, mas de vários projetos de natureza territorial, os quais podem convergir, mas também conflitar em termos de natureza, conteúdo e objetivos. Projetos que muitas das vezes exploram uma mesma narrativa que evoca os mesmos valores de uma identidade compartilhada, ou de uma mesma matriz cultural, como é precisamente o caso do que aqui denominamos "italianidade".

Feita essa ponderaçáo, cabe agora analisar o caso da IPVV sob o prisma dessas vertentes interpretativas. Que aspectos sáo claramente perceptíveis para explicar o êxito dessa iniciativa do ponto de vista do capital social ali presente? Não é irrelevante dizer que a vitivinicultura representa um poderoso marcador de uma identidade forjada ao sabor das circunstâncias relativas à difícil adaptaçáo dos pioneiros a uma terra inóspita, muito distante, decerto, do paese della cucagna ${ }^{15}$ que seduziu muitos colonos a virem para o Brasil. Tais dificuldades sedimentaram as bases para que aflorassem experiências associativas importantes ligadas ao mundo da uva, do vinho e de outros produtos.

Com efeito, a IPVV náo pode ser vista simplesmente como uma mera ferramenta mercadológica de promoção de um produto de qualidade diferenciada, mas precisa ser considerada como um instrumento de desenvolvimento que se nutre de uma herança cultural e histórica extremamente potente e que está ancorado num território específico, em torno do qual outras iniciativas possam aflorar (o turismo, a gastronomia, a prestação de serviços etc.).

Mas, será que os resultados dessa construçáo capitaneada pela indicaçáo geográfica fortalecem, efetivamente, a plenitude dos setores constituintes do

15 Trata-se de um país lendário, que povoava a mente dos imigrantes italianos, os quais sonhavam com uma terra em que brotavam raviolis das árvores, onde jorrava vinho e a riqueza era infinita, retratado na tela de Pieter Brueghel (século XVII). Essa imagem fazia parte do discurso alardeado pelos agentes de companhias de imigração que operavam no suculento negócio de arregimentação de trabalhadores para colonizar as terras do Novo Mundo. 
tecido social e produtivo de um dado território? Essa questáo remete o leitor para uma discussáo que extrapola os limites deste estudo. Consideramos, destarte, que é necessário um acúmulo de experiências que nos permitam afiançar a veracidade dessa hipótese.

Outrossim, o que está claro é que a evoluçáo do mundo dos vinhos e a necessidade de adaptaçáo a um cenário cada vez competitivo e desafiador fizeram emergir uma experiência que se baseia, fundamentalmente, na confiança, na cooperaçáo e na capacidade de inovaçáo de diversos atores. Um ambiente que fez surgir estruturas de governança (Conselho Regulador) que atualmente exercem suas funçóes para além do universo da vitivinicultura, como no caso de influir na discussão sobre o Plano Diretor dos municípios que conformam a indicaçáo geográfica, com o fito de frear a especulaçáo imobiliária ${ }^{16}$, notadamente a criaçáo de condomínios de luxo na área delimitada pela IPVV.

A construçáo das antigas capelas e centros comunitários, a criação de associaçóes comunitárias para gerir a distribuição de água, o financiamento assumido de forma compartilhada pelas famílias para construçáo e extensão de redes de eletrificaçáo e de telefonia podem ser vistos como manifestação do capital social de uma regiáo que, obviamente, extrapola a área delimitada pela IPVV. Todavia, também é certo dizer que a esses aspectos somam-se outras questóes igualmente importantes, como a preocupaçáo de preservar a beleza cênica de paisagens desenhadas pela mão do homem, tal qual é o caso dos parreirais, dos caminhos rurais e dos velhos casaróes de pedra.

Coincidimos com Ortega e Jeziorny (2011, p. 117) quando estes concluem:

Portanto, é cabível de se entender que, no Vale dos Vinhedos, há reciprocidade, cooperação, número de jogadores e informações a respeito da reputação de cada indivíduo. É justamente a existência de todas essas condições que, segundo Putnam (2000) I7, facilita o surgimento de um bom estoque de capital social.

O caso da IPVV, que hoje conquistou a condição de denominaçáo de origem para seus vinhos e espumantes, demonstra de forma cabal que a competiçáo e a cooperaçấo náo podem ser vistas como conceitos que se opóem

16 Curiosamente, é esse um dos grandes desafios enfrentado pelos produtores de uva e vinho da região italiana de Chianti. Ver, a esse propósito, o estudo de Brunori e Rossi (2007).

17 Os autores se referem ao trabalho já citado, por nós, anteriormente. 
ou se excluem mutuamente. As empresas que se organizam em torno de um projeto desta natureza, que inclui outras iniciativas similares (sobretudo as ligadas ao enoturismo) buscam, de forma coordenada e articulada, veicular, simultaneamente, uma imagem do próprio território e uma narrativa centrada na própria identidade.

E, se essa construçáo exprime com bastante clareza o que até aqui vimos comentando, parece igualmente interessante reproduzir a pergunta feita por Durston (1998) na epígrafe de seu trabalho, qual seja: "como criar capital social onde ele não existe?”. A resposta a essa questão remete o leitor à discussão formulada na segunda seçáo deste estudo. Antes de retomá-la, convém analisar a segunda experiência de indicação geográfica que elegemos neste trabalho.

\subsection{Carne e derivados do Pampa Gaúcho da Campanha Meridional}

A introduçáo do gado vacum, no Sul do Brasil e nos demais países do Cone Sul, está indissoluvelmente ligada ao processo de ocupação do território e ao surgimento das reduçóes jesuíticas durante a primeira metade do século XVII. A história dos chamados "Sete Povos Missioneiros" relata a produçáo de couro e de sebo como uma das atividades econômicas mais importantes desenvolvidas nas antigas reduçóes. Os sucessivos ataques dos bandeirantes paulistas na preação dos índios catequizados e a destruiçáo protagonizada, durante o século XVIII, pelas duas coroas ibéricas na chamada 'guerra guaranítica', implicaram o fim das reduçôes.

Após a expulsão dos jesuítas, restou o gado trazido por estes, o qual, abandonado à própria sorte, nas amplas planícies, converteu-se em imensos rebanhos selvagens, também chamados cimarrones. $\mathrm{O}$ período subsequente corresponde ao surgimento das estâncias e grandes invernadas, em que o gado era criado e engordado para ser comercializado dentro e fora das fronteiras do Brasil meridional.

A demanda de animais para o abate e de animais de tiro (especialmente mulas), cresce rapidamente com a intensificação das atividades econômicas, fazendo surgir uma atividade igualmente importante, qual seja, a de tropeiro, que conduzia os rebanhos do Rio Grande do Sul até a famosa feira de Sorocaba em Sáo Paulo, onde os animais eram negociados. Outra atividade econômica de vulto, ligada diretamente ao ciclo da mineraçáo do sudeste brasileiro, corresponde à produçáo saladeril, desenvolvida nas grandes charqueadas do Rio 
Grande do Sul, cujo produto (charque) era destinado à alimentaçáo da mão de obra escrava, sendo, inclusive, exportado para outros países (EUA e Cuba) para cumprir esse mesmo propósito.

A imagem icônica do gaúcho, ou do "centauro dos pampas" que manejava os rebanhos, vai sendo forjada através do tempo no Sul do Brasil, assim como nos demais países do Prata, sobretudo por força dos sucessivos conflitos territoriais e das guerras de independência protagonizadas pelas milícias lideradas pelos grandes coronéis e pela chamada 'aristocracia do charque'.

Do ponto de vista econômico, a grande mudança ocorre a partir da introdução das chamadas raças britânicas (Devon, Angus, Hereford), ao final do século XIX e começo do século XX, que se adaptaram facilmente ao ambiente pampeano. São animais produzidos em criaçóes extensivas, alimentados naturalmente nos pastos nativos, que guardam um padráo de excelência de uma carne que é apreciada pelos consumidores e internacionalmente reconhecida por seus atributos de qualidade. Por força desse intuito de diferenciaçáo, criou-se a Indicação de Procedência da Carne e derivados do Pampa Gaúcho da Campanha Meridional (doravante referida como IPCPG). Antes de entrar propriamente nessa questáo, convém comentar alguns aspectos gerais.

A regiáo pampeana compreende uma superfície de aproximadamente 700 mil km² que se estende pela Argentina, pelo Uruguai e pelo Brasil. A parte brasileira desse bioma está integralmente circunscrita ao Rio Grande do Sul, é formada de campos nativos e compreende uma área de $157 \mathrm{mil} \mathrm{km}^{2}$, equivalente a quase $2 / 3$ do território gaúcho, que abriga em seu interior grande fonte de biodiversidade animal e vegetal. Segundo Boldrini (1997), são nada menos que 400 espécies de gramíneas forrageiras e 150 espécies de leguminosas.

Paradoxalmente, o Pampa é um dos Biomas com menor percentual de área legalmente protegida em nosso país. Segundo documento do Ministério do Meio Ambiente, a progressiva introdução e expansão das monoculturas e de pastagens com espécies exóticas conduziram a uma rápida degradaçáo e descaracterização das paisagens do pampa. Soma-se a isso a expansáo dos grandes projetos de plantio de eucalipto apoiados, inclusive pelo governo estadual, bem como, em maior ou menor medida, o crescimento da lavoura arrozeira irrigada. 
Nesse sentido, estimativas de perda de hábitat dáo conta de que, em 2002, restavam 41,32\% da vegetação nativa do bioma Pampa, e que, em 2008, esse percentual havia reduzido para somente 36,03\% (BRASIL, 2010). É importante reter esse aspecto para entender o conteúdo da narrativa que se elabora em torno da criaçáo da indicaçáo de procedência.

Reconhecida oficialmente pelo INPI, em 2006, a IPCPG surgiu a partir do incentivo do SEBRAE (Serviço Brasileiro de Apoio às Micro e Pequenas e Empresas), Serviço Nacional de Aprendizagem Rural (SENAR), da Federação de Agricultura do Estado do Rio Grande do Sul (FARSUL) e do apoio técnico prestado por pesquisador da Universidade Federal do Rio Grande do Sul (UFRGS).

A Criação da Associaçáo dos Produtores do Pampa Gaúcho da Campanha Meridional (Apropampa) é fruto desse processo, que, à época, integrava, segundo Cerdan (2009, p. 289), 66 pecuaristas, dois comerciantes e um abatedouro. $\mathrm{O}$ caráter extensivo dessa atividade fica evidenciado quando aludimos ao tamanho dos estabelecimentos, cujas dimensóes oscilam entre aproximadamente 500 e 15.000 hectares, locais em que tanto se podem realizar o ciclo completo (cria, recria e engorda) quanto apenas a fase de terminaçáo dos animais. A área delimitada pela IPCPG é de aproximadamente 1,2 milháo de hectares, recobrindo parte dos municípios de Bagé, Aceguá, Hulha Negra, Pedras Altas, Lavras do Sul, Dom Pedrito, São Gabriel e Santana do Livramento.

O Caderno de Normas da IPCPG admite somente as raças Angus, Hereford e seus cruzamentos, sendo que a alimentaçáo dos animais há que ser feita através de pasto nativo ou pasto nativo melhorado, podendo serem terminados em pastagens cultivadas de inverno (nativas ou exóticas), mas em regime extensivo. Outro aspecto fundamental é a exigência obrigatória de rastreabilidade dos animais, cuja idade de abate tem de ser inferior a 42 meses. O processo de construçáo social da qualidade é extremamente complexo e marcado por muitos conflitos, na medida em que boa parte dos produtores resiste às restriçóes impostas no caderno de normas, sobretudo no que afeta as raças admitidas e a rastreabilidade dos animais, como assim o demonstra um de nossos entrevistados:

Sim, mas há muita resistência do ponto de vista do que, como te posso dizer? Os produtores, pecuaristas no Rio Grande do Sul, têm muita tradição no que fazem. Desde seu avô. $A$ 
princípio isso ajudaria [...]. Mas há coisas por trás que os fazem... Hoje, se [sic] mantêm na atividade porque, não sei se me explico, é muito social o tema, tá, muito comportamental. Está, todavia... Tem muitos paradigmas. E uma dessas coisas são as raças, por exemplo. Se vou dizer que, para entrar na APROPAMPA, tem que [sic] produzir novilhos Hereford, e teu avô tinha uma outra raça que não era Hereford... Se alguém te diz que tens que tens que [sic] mudar para Hereford para ganhar mais, tu não vai mudar a raça. Se vão produzir novilhos de cinco anos de idade, e vem à APROPAMPA, e agora te dizem que tens que [sic] produzir novilhos de dois anos, não vai [sic] produzir. Se vêm à APROPAMPA e te dizem que vão ter que [sic] fazer a rastreabilidade, mas nunca fez, porque não tem controle, isso te dá mais trabalho, não vai registrar. Então, a cultura é boa, mas também é muito social o tema, me entendes? Não sei se me explico bem... ${ }^{18}$

Tradicionalmente, essa atividade econômica é marcada pelo conservadorismo dos produtores, que, não obstante a introduçáo de diversas inovaçóes tecnológicas, são bastante refratários à incorporaçáo de mudanças organizacionais. De certo modo, essa tendência reflete uma cultura moldada através do tempo no tradicionalismo das antigas estâncias lideradas por grandes proprietários, cuja atuaçáo era marcada pelo cariz individualista e pelo atomismo em suas relaçóes com o mundo externo, para além das velhas mangueiras de pedra que resistem ao tempo em muitas das propriedades pampeanas.

Seria esse um traço atávico da alma campeira ${ }^{19}$ que desafia o tempo e as grandes transformaçóes da sociedade da informação e da tecnologia? A resposta a essa questáo ultrapassa os limites deste trabalho e cumpre o propósito de táo somente prospectar algumas das razóes que explicam as grandes dificuldades de desenvolver projetos associativos territorialmente ancorados nessa parte da geografia gaúcha, sobretudo nesse setor da atividade econômica.

Por outro lado, as relaçóes com os frigoríficos são historicamente marcadas por conflitos, sendo recorrentes as falências dessas empresas, sejam elas de natureza eminentemente privada ou mesmo cooperativada. O caso da IPCPG mostra as contradiçóes de um processo de organizaçáo que pouco tem avançado se temos em mente que, atualmente, inexiste produçáo de carne comercializada sob esse selo ou condição.

18 Entrevista concedida em Bagé no dia 26 de junho de 2012.

19 Dentre as obras de José de Alencar, figura "O Gaúcho" (1998 [1870], p. 3), por muitos desconhecida. Nas palauras desse imortal das letras brasileiras, o aludido personagem é assim definido: "Como a árvore, são a ema, o touro, o corcel, todos os filhos bravios da savana. Nenhum ente, porém, inspira mais energicamente a alma pampa do que o homem, o gaúcho. De cada ser que povoa o deserto, toma ele o melhor; tem a velocidade da ema ou da corça; os brios do corcel e a veemência do touro.". 
A Marfrig Alimentos consiste no principal destino da produçáo bovina de qualidade (com rastreabilidade), sendo a primeira indústria do ramo a adotar as principais modalidades internacionais de certificaçóes. Todavia, o contato com a realidade mostrou que a comercializaçáo de carne com indicação de procedência é ainda uma quimera. Essa empresa, que firmou parceira com a Apropampa, valoriza a raça animal (sobretudo Aberdeen Angus) com um preço prêmio correspondente, por se tratar de um produto diferenciado.

Mostrar a importância da pecuária extensiva na preservaçáo ambiental foi assumido como parte de um discurso mais amplo que marcou a aproximaçáo com uma organizaçáo náo governamental (ONG) - La Alianza del Pastizal - que integra pecuaristas e atores sociais da cadeia de carnes da Argentina, do Uruguai, do Brasil e do Paraguai. Em linhas gerais, trata-se de defender o papel dessa atividade na conservaçáo da biodiversidade ${ }^{20}$, especialmente quando sáo evidentes, como vimos anteriormente, as ameaças de degradaçáo do bioma "Pampa brasileiro".

Mas que motivos, concretamente, existem para que a proposta da IPCPG não consiga avançar em seus propósitos? Por que razão esse sinal distintivo é absolutamente desconhecido pelos consumidores gaúchos e brasileiros? Na seçáo precedente, vimos que a regiáo do Vale dos Vinhedos dispóe dos serviços prestados pela Embrapa Uva e Vinho de Bento Gonçalves, que desempenhou um papel estratégico na criaçáo da IPVV. Do mesmo modo, a regiáo que cobre a área delimitada pela IPCPG conta com uma instituição tradicional de pesquisa - a Embrapa Pecuária Sul - sediada em Bagé, dedicada à produçáo de conhecimento e de inovação nesse âmbito. Por que razão as duas IGs vivenciam trajetórias táo distintas? As singularidades relativas à pecuária extensiva, enquanto atividade produtiva, sáo suficientes para explicar as diferenças entre estas duas estratégias de diferenciação de produtos agroalimentares? A próxima subseçáo busca respostas para essas questóes.

\subsection{O Capital Social na região da Apropampa}

A orientaçáo primordial que moveu a criação da Apropampa e da própria IPCPG era a de diferenciar-se de outros sistemas de produçáo, sobretudo do

20 Esta ONG se vincula a outras organizações do gênero, conhecidas internacionalmente, como é o caso da BirdLife International. Ver, a esse propósito, http://www.pastizalesdelconosur.org/index.php/es/vi-encuentro-de-ganaderos-de-pastizales-naturales-del-cono-sur.html. 
que é praticado em outras regióes do país como o Brasil central, onde predominam raças zebuínas e a produçáo visa atender, fundamentalmente, aos consumidores menos exigentes e às grandes superfícies de varejo. A marca das raças britânicas, indubitavelmente, é a qualidade de um produto obtido em condiçóes muito especiais, potencialmente apto à exportaçáo através da incorporaçáo da rastreabilidade e de convençóes de qualidade. Mas o quadro atual desse processo de organizaçáo dista muito desse propósito no caso da IPCPG.

Nesse sentido, no trecho a seguir, consta a avaliaçáo feita em pesquisa recente, a qual descreve um cenário da IPCPG que pouco se modificou através do tempo. No contato com a realidade, chegamos a conclusóes idênticas ao que alude o autor quando este afirma:

La puesta en mercado se caracteriza por la presencia de dos distribuidores. El primero es un comercio que ofrece especialidades, situado en Porto Alegre, capital del Estado de Rio Grande do Sul. El segundo es un comercio de la cadena de supermercados Perruzo, localizado en Bagé. A pesar del interés que despierta este proyecto en los actores locales involucrados, la relevancia económica del mismo permanece marginal. De hecho, hasta el momento la faena se sitúa en unos 50 animales por semana (promedio para el año 2007). Por el momento, la escasa relevancia del volumen faenado no alcanza a generar expectativa en el mercado nacional y menos aún pensar en una proyección internacional. (CHAMPREDONDE et al., 2008, p. 12).

Não é preciso muito esforço para apontar as flagrantes as diferenças existentes entre ambos os territórios aqui cotejados do ponto de vista da densidade institucional. No caso da carne, a busca de singularizaçáo de um produto de qualidade esbarra na ausência de estruturas de governança que contemplem o conjunto de atores dessa cadeia produtiva em torno de uma ideia-guia que fica totalmente à mercê das determinaçóes de um único frigorífico. A experiência mundial demonstra que uma indicaçấo geográfica representa uma ferramenta coletiva de promoção de um produto portador de identidade e de tipicidade. Todavia, é impossível pensar num processo de construçáo social da qualidade que renuncie, ao fim e ao cabo, aos princípios do associativismo, da confiança e da coesáo social.

A fragilidade desse processo aparece claramente evidenciada no fato de que, não obstante ser esta uma atividade de importância capital para a economia e para a identidade regional, a Apropampa nem sequer dispóe de um espaço próprio para o desenvolvimento de suas atividades, como bem explica um de nossos entrevistados: 
São as indicações geográficas um instrumento para o desenvolvimento dos territórios? Estudo de caso sobre duas experiências no estado do Rio Grande do Sul | Flávio Sacco dos Anjos - Fernanda Novo da Silva - Nádia Velleda Caldas - Germano Ehlert Pollnow

Na medida que nós participamos do conselho regulador, a Embrapa oferece o próprio local de reuniōes pros conselhos da Apropampa se reunirem aqui. Como um ponto central, como a Apropampa não tem sede própria, né, então, coisas pequenas, como essa, até a discussão na participação dos processos, da ajuda, no desenvolvimento... Agora mesmo nós estamos discutindo a retomada do produto ao consumidor, porque houve uma troca do frigorifico que fazia o abate, dos donos do frigorífico. [...]. Antes era outro proprietário, [...] a planta frigorifico é a mesma, mas em função dessa troca houve um processo de quebra no fornecimento da carne ao consumidor. Então, agora nós estamos retomando as negociações pra começar... ${ }^{21}$

$\mathrm{O}$ depoimento acima mostra que, transcorridos mais de seis anos desde sua criação, a IPCPG é ainda um projeto em construçáo. A natureza extensiva da atividade, com seus desdobramentos negativos sobre a interaçáo dos atores sociais, náo pode ser vista como a causa única e exclusiva do insucesso dessa iniciativa. As causas são bem mais profundas e remetem a uma discussão mais ampla que envolve o capital social dos territórios. Nesse sentido, convergimos para a posiçáo assumida por um autor que exprime, de forma magistral, esse mesmo entendimento:

Diante de novos problemas que requerem solução coletiva, homens e mulheres de toda parte vão buscar soluções no seu próprio passado. Os cidadãos das comunidades cívicas descobrem em sua história exemplos de relações horizontais bem-sucedidas, enquanto os cidadãos das regiões menos cívicas encontram, quando muito, exemplos de suplicação vertical. (PUTNAM, 2000, p. 184).

Na visáo crítica exposta por Champredonde et al (2008), ao analisarem o projeto de criação da IPCPG, outros aspectos são incorporados. Nesse estudo, afirmam que os critérios adotados na construção do caderno de normas refletem muito mais as exigências do mercado do que propriamente uma traduçáo fiel das práticas predominantes no universo de exploraçóes agropecuárias da Campanha meridional. $\mathrm{O}$ volume insignificante de carne vendida com o selo da IPCPG exprime não somente a incapacidade de cumprir o próprio protocolo, mas também o escasso retorno que pode representar em termos monetários para os criadores.

$\mathrm{O}$ fato de ter sido uma iniciativa que envolve pecuaristas que detêm extensas áreas náo pode ocultar o fato de que existem pequenos proprietários, cujo número é bastante superior ao dos primeiros, os quais vivem também da

21 Entrevista concedida em Bagé no dia 25 de junho de $20 / 2$ 
produção de gado e de ovinos, e que foram 'naturalmente' excluídos de participar desse projeto. Não obstante, são claros e evidentes os indícios da escassa capacidade de articulaçáo daqueles que um dia imaginaram levar adiante essa iniciativa. Nem os objetivos mercadológicos foram atendidos, muito menos a ideia de converter esse processo numa estratégia incrustada no território a partir de alianças que fizessem expandir as oportunidades para além das próprias fronteiras.

Quem ou o que precisamente foi responsável por liderar a iniciativa de criação da IPCPG? O depoimento, a seguir, satisfaz essa indagaçáo de forma muito cristalina:

Não era uma ideia dos produtores. Não foram os produtores que identificaram que a indicação geográfica poderia ser uma boa coisa para eles. Foi o SEBRAE, foi a ideia do professor $X$, foi a ideia de alguém da Embrapa, entendes? Não surgiu dos produtores. Essa é uma questão importante, muito importante. E por aí passa muitas coisas que hoje ocorrem dentro da associação [...] Há muita dificuldades ainda que não foram superadas. Falta muita organização interna. Falta envolver mais os produtores, porque nasceu dessa forma. Havia uma consultoria para isso... Creio que, hoje é JK, secretário executivo, lá atrás havia uma outra pessoa, que o SEBRAE reportava recursos, que pagava. E, bom, a associação nasceu da ideia de uma indicação geográfica para os produtores, tinham várias coisas no objetivo22.

O fato de náo haver sido um projeto capitaneado pelos próprios pecuaristas náo pode ser visto como um fato necessariamente impeditivo para que a IPCPG pudesse avançar, tal como tantas outras experiências do gênero. Sabemos que é esse, precisamente, um dos papéis cruciais reservados às diversas agências e instituiçóes identificadas com o desenvolvimento dos territórios, como é o caso do SEBRAE, da Embrapa e das universidades. O problema é que existem obstáculos bastante grandes a serem transpostos nessa regiáo e nesse ramo de atividade sócio-produtiva, dificuldades estas que mostram que nem sempre tradiçáo e inovaçáo andam de máos dadas. O exemplo em epígrafe atesta que podem, inclusive, se apresentar em franca oposiçáo.

\section{Conclusões}

Os dados que apresentamos na terceira seçáo deste trabalho evidenciaram, de modo insofismável, o notável crescimento no número de indicaçóes geográficas existentes no Brasil. Entretanto, como aludimos anteriormente,

22 Entrevista concedida em Bagé no dia 25 de junho de 2012. 
em nosso país, esse tipo de sinal distintivo pode ser usado tanto para produtos agroalimentares quanto para utensílios domésticos (facas, tesouras, pedras etc.), mostrando quáo distantes ${ }^{23}$ podem ser as concepçóes que inspiraram esses processos, no Brasil, em relação às demais experiências internacionais.

Destarte, não foi precisamente esse o eixo da reflexão que levamos a efeito nos limites deste estudo, cujo foco primordial esteve orientado a indagar em que medida esses dispositivos representam um instrumento eficaz no afá de impulsionar a inovaçáo, nos territórios, mediante processos de cooperaçáo e de coesáo social. A resposta a essa questáo não é simples. Deixamos isso patente ao discorrer, criticamente, sobre a trajetória de duas experiências de indicação geográfica existentes no Rio Grande do Sul.

Nessa tarefa, lançamos máo de duas ferramentas interpretativas que consideramos capazes de iluminar tal debate. Promover a expansáo de uma determinada atividade econômica ou cadeia produtiva, de maneira alguma, pode ser visto como uma via capaz de impulsionar o desenvolvimento dos territórios, sobretudo naquelas regióes marcadas por uma escassa densidade do tecido social e produtivo e por uma forte tradiçáo de verticalidade nas relaçóes políticas e socioculturais.

O caso do Vale dos Vinhedos é emblemático na medida em que mostra como uma organizaçáo, surgida em meio a uma grande crise que afetava a vitivinicultura brasileira durante os anos 1990, foi inicialmente responsável por imprimir uma nova dinâmica, ao organizar todo um setor, mediante a criaçáo de uma associaçáo, cujo processo de articulaçáo culminou, entre outros aspectos, na constituição da primeira Indicaçáo Geográfica do Brasil.

Entrementes, ao longo do tempo, a Aprovale passa a incorporar outros papéis, inclusive o de converter-se no que os estudiosos do tema (NAVARRO; AZCÁRATE, 1995; ORTEGA, 2005) denominam de interprofissional, ou seja, numa organizaçáo que congrega em torno de si os interesses dos diversos atores (agricultores, vinicultores, empresários etc.) de uma cadeia de valor referida a um produto, que é a marca indiscutível da italianidade.

O horizonte de atuaçáo da Aprovale se depara hoje com outros desafios, como é a questáo do Plano Diretor dos municípios frente aos efeitos produzidos

23 Sobre essa questão dos problemas em torno da institucionalização das indicações geográficas no Brasil, ver os estudos de Niederle (2011) e de Silva et al (2012). 
pela espiral especulativa das terras, que acometem a regiáo onde se acha delimitada a indicação geográfica. Por outro lado, a recente criação da Denominação de Origem Vale dos Vinhedos traz consigo outras implicaçóes, tal qual, precisamente, o caso da ampliaçáo das restriçóes com relação à origem da uva, à quantidade colhida por planta e outros requisitos que fazem parte de um novo caderno de normas ainda mais rigoroso que o da IPVV, bem como de novas convençóes de qualidade.

Sob um ambiente de incertezas, como é precisamente o que estamos vivendo, e que atinge implacavelmente os mais recônditos âmbitos da vida social, torna-se imperativo que os atores sociais estabeleçam uma estrutura de governança que aglutine, em torno de si, o conjunto de demandas e interesses das forças vivas do território. A ideia-guia é forjada a partir de uma identidade compartilhada e de um ambiente institucional que impele à cooperaçáo.

Por outra parte, o caso da IPCPG ilustra, de forma cabal, quão complexa é a missáo de criar capital social num ambiente em que praticamente inexiste uma predisposiçáo à cooperaçáo, à inovaçáo e à coesáo social. Referimo-nos a uma regiáo que possui uma identidade calcada na imagem icônica do gaúcho, na qualidade de um produto (a carne e seus derivados) e na beleza de suas paisagens, mas que, paradoxalmente, enfrenta grandes resistências para ultrapassar as fronteiras do atomismo dos produtores e a desarticulaçáo dos atores do território. Concretamente, há limites para converter-se numa comunidade cívica, enfatizada nos estudos sobre capital social, especialmente porque os agentes se mostram incapazes de 'erigir pontes', parafraseando Putnam (2000), e de interagir com outros atores sociais para além da própria porteira.

Os exemplos aqui confrontados e a noção de capital social nos convidam a refletir sobre a importância dos processos de cooperação. Remetem-nos à eterna discussáo sobre a natureza hobbesiana de uma sociedade regida agora pelo império da globalizaçáo e pela diluiçáo das fronteiras físicas e identitárias.

Há, decerto, toda uma tradiçáo filosófica dedicada a esse controvertido assunto, a exemplo da conhecida obra - A Fábula das Abelhas - de Bernard de Mandeville, publicada no séc. XVIII e conhecida pelo slogan famoso 'Vícios privados, virtudes públicas', o qual se converteu em verdadeiro mantra para os apologistas do individualismo mercantil, defendendo a tese de que a riqueza é gerada e se expande a partir do instante em que as pessoas voltam-se para 
atender os próprios interesses. Uma doutrina em que não há espaço para a virtude e para o civismo, e que se apresenta plenamente afinada com a cantilena liberal idealizada na 'mão invisível' de Adam Smith. Decididamente, não é esse o caminho a ser trilhado na construçáo de um projeto dessa envergadura.

As indicaçóes geográficas podem converter-se, decididamente, num instrumento de desenvolvimento territorial, sempre e quando outras condiçóes e circunstâncias estejam presentes, sobretudo quando se pensa na necessidade de constituir um sujeito coletivo em torno a uma ideia-guia que expresse a capacidade de articulaçáo dos vetores dinâmicos do território. Portanto, uma das principais liçóes que se pode extrair das duas experiências aqui cotejadas é a de que a criaçáo de uma indicaçáo geográfica, decididamente, há que ser vista, náo como o destino final de um processo, mas como ponto de partida de uma longa caminhada de construçáo social da qualidade, da diferenciaçáo e de fortalecimento da própria identidade.

\section{Agradecimentos}

Este trabalho foi realizado com o apoio da Fundaçáo de Amparo à Pesquisa do Rio Grande do Sul, Processo no 11/2044-2 (PRONEM), da CAPES (Acordo de Cooperaçáo Brasil-Espanha) e do CNPq.

\section{Referências}

ABRAMOVAY, R. O futuro das regióes rurais. Porto Alegre: Ed. da UFRGS, 2003.

Para una teoría de los estudios territoriales. In: MANZANAL, M.; NEIMAN, G.; LATTUADA, M. (Org.) Desarrollo Rural. Organizaciones, instituciones y territorios. Ciccus: Buenos Aires, 2006, p. 51-70.

ACAMPORA, T.; FONTE, M. Productos típicos, estrategias de desarrollo rural y conocimiento local. Opera, n. 7, p. 191-212, 2007.

ALENCAR, J. de. O gaúcho. 3. ed. Sáo Paulo : Ática, 1998 [1870]. Disponível em: <www. dominiopublico.gov.br/pesquisa/DetalheObraForm.do?select_action=\&co_obra $=1842>$. Acesso em: 22 set. 2012.

ALIANZA DEL PASTIZAL. Disponível em: <www.pastizalesdelconosur.org/>. Acesso em: 8 out. 2012. 
ANJOS, F. S. Agricultura Familiar, Pluriatividade e Desenvolvimento Rural no Sul do Brasil. Pelotas: EGUFPEL, 2003. 374p.

.; CALDAS, N. V. Construindo a segurança alimentar? A experiência recente dos CONSADs no Brasil Meridional. RESR, Rio de Janeiro, v. 45, n. 03, p. 645-673, 2007.

BOLDRINI, I. I. Campos do Rio Grande do Sul: Caracterizaçáo fisionômica e problemática ocupacional. Boletim do Instituto de Biociências, n. 56, 1997.

BRASIL. Ministério do Meio Ambiente (MMA). Instituto Brasileiro do Meio Ambiente e Recursos Naturais Renováveis, Centro de Sensoriamento Remoto. Monitoramento do Desmatamento dos Biomas Brasileiros por Satélite. Brasília, 2010. Disponível em: <http://siscom.ibama.gov.br/ monitorabiomas/pampa/RELATORIO_PAMPA_2008_PMDBBS.pdf>. Acesso em: 5 dez. 2012.

BRASIL. Presidência da República. Lei no 9.279, de 14 de maio de 1996. Regula direitos e obrigaçóes relativos à propriedade industrial. Disponível em: <www.planalto.gov.br/ccivil_03/leis/ L9279.htm>. Acesso em: 3 dez. 2012.

BRUNORI, G.; ROSSI, A. Differentiating countryside: Social representations and governance patterns in rural areas with high social density: The case of Chianti, Italy. Journal of Rural Studies, v. 23, p. 183-205, 2007.

CERDAN, C. Valorizaçáo dos produtos de origem e do patrimônio dos territórios rurais no sul do Brasil: Contribuiçâo para o desenvolvimento territorial sustentável. Política \& Sociedade, v. 8, n.14, p. 277-299, 2009.

.; SOUZA, M. C. M.; FLORES, M. El patrimonio cultural como un elemento estratégico para el desarrollo territorial: dos casos de la inmigración italiana en Brasil. In: RANABOLDO, C.; SCHEJTMAN, A. (Ed.), El valor del patrimonio cultural. Territorios rurales, experiencias y proyecciones latinoamericanas. Lima: IEP Rimisp, 2009. p. 303-319.

CHAMPREDONDE, M. et al. La Pampa como indicación geográfica para diferenciar carnes vacunas en Argentina y en Brasil: motivaciones de los actores locales, limitantes para su implementación. In: IV Congreso Internacional de la Red SIAL, Mar del Plata 27 al 31 de octubre de 2008, Anales..., 2008.

COLEMAN, J. Foundations of social theory. Cambridge, Londres: The Belknap Press of Harvard University Press, 1990.

DURSTON, J. Building social capital in rural communities (where it doesn't exist). Theoretical and policy implications of peasant empowerment. in Chiquimula, Guatemala. Latin American Studies Association (LASA), The Palmer House Hilton, Chicago, II, September, p. 24-26, 1998. 
São as indicações geográficas um instrumento para o desenvolvimento dos territórios? Estudo de caso sobre duas experiências no estado do Rio Grande do Sul | Flávio Sacco dos Anjos - Fernanda Novo da Silva - Nádia Velleda Caldas - Germano Ehlert Pollnow

ESTRADA, E. M. Capital Social y Desarrollo em Zonas Rurales. In: MANZANAL, M.; NEIMAN, G.; LATTUADA, M. Desarrollo Rural. Organizaciones, instituciones y territorios (Org). Ciccus: Buenos Aires, 2006. p. 103-128.

FAVARETO, A. A abordagem territorial do desenvolvimento rural - mudança institucional ou “inovaçáo por adiçáo”. Estudos Avançados, v. 24, n. 68, p. 298-319, 2010.

Paradigmas do desenvolvimento rural em questáo. São Paulo: Fapesp, Ed. Iglu, 2007.

GAIGER, L. I. A práxis coletiva dos sem-terra rumo à unidade ou à heterogeneidade cultural? Cadernos de Sociologia, n. 6, p. 177-203, 1994.

GOODMAN, D. The quality 'turn' and alternative food practices: reflections and agenda. Journal of Rural Studies, v. 19, n. 1, p. 1-7, 2003.

GRANOVETTER, M. Economic action and social structure: the problem of embeddeness. American Journal of Sociology, n. 91, p. 481-493, 1985.

. The old and the new Economic Sociology: a history and an agenda. In: FRIEDLAND, R.; ROBERTSON, A.F. (Ed.). Beyond the marketplace: rethinking economy and society. New York: Aldine de Gruyter, 1990. p. 89-112.

The Strength of Weak Ties. American Journal of Sociology, v. 78, n. 6., May, p. 13601380, 1973.

HERVIEU, B. Los Campos del Futuro. Madrid: Ed. MAPA, 1996.

MACHADO, N. M. C. Karl Polanyi e a nova sociologia econômica: notas sobre o conceito de (dis) embeddedness. Revista Crítica de Ciências Sociais, v. 90, set., p. 71-94, 2010.

NAVARRO. A. L.; AZCÁRATE, T. G. Las interprofesionales agroalimentarias en Europa. Mapa: Madrid, Serie Estudios, 1995.

NIEDERLE, P. A. Compromissos para a qualidade: projetos de indicaçáo geográfica para vinhos no Brasil e na França. Tese (Doutorado em Ciências Sociais) - Universidade Federal Rural do Rio de Janeiro, Rio de Janeiro, 2011.

Controvérsias sobre a noçâo de indicaçóes geográficas enquanto instrumento de desenvolvimento territorial: a experiência do Vale dos Vinhedos em questáo. In: 470 Congresso Brasileiro de Economia, Administraçáo e Sociologia Rural, Anais..., Porto Alegre: SOBER, 2009.

ORTEGA, A. C. Agronegócios e representaçáo de interesses no Brasil. Uberlândia: Edufu, 2005. .; JEZIORNY, D. L. Vinho e Território. A experiência do Vale dos Vinhedos. Campinas: Alínea, 2011. 
PUTNAM, R. D. Comunidade e democracia: A experiência da Itália moderna. Rio de Janeiro: Fundaçáo Getúlio Vargas Editora, 2000.

PUTNAM, R. D. Bowling Alone. American's declining social capital. Journal of Democracy, v. 6, n. 1, p. 65-78, 1995.

SILVA, F. N. et al. Desafios à institucionalizaçáo das indicaçôes geográficas no Brasil. Desenvolvimento Regional em Debate, Canoinhas, v.2, n.2, p. 31-44, 2012.

TEDESCO, J. C. Contratualização e racionalidade familiar. In: TEDESCO, J.C. (Comp.) Agricultura familiar: realidades e perspectivas, Passo Fundo, EDIUPF, 1999, p. 107-145.

TONIETTO, J. Experiências de desenvolvimento de indicaçóes geográficas: vinhos da indicação de procedência Vale dos Vinhedos. In: LAGES, V.; LAGARES, L.; BRAGA, C. L. (Org.), Valorizaçáo de produtos com diferencial de qualidade e identidade: indicaçóes geográficas e certificaçóes para competitividade nos negócios, Brasília: Sebrae, 2006. p. 155-176.

VEIGA, J. E. A face rural do desenvolvimento: natureza, território e agricultura. Porto Alegre: Ed. UFRGS, 2000.

Recebido em: 23/12/2012

Aprovado em: 15/03/2014

\section{Are geographical indications a tool for the development of the territories? Case study of two experiences in the state of Rio Grande do Sul}

\section{Abstract}

This paper examines the issue of geographical indications as a tool for the development of the territories. The authors present a review on the subject, offering an opportunity to know two experiences of geographic indications in the state of Rio Grande do Sul (wines of the Vale dos vinhedos and meat of Pampa Gaúcho da Campanha meridional). The two cases have enormous differences. The conclusion that the authors reach is in order to show that the success of these experiences is governed by the existence of social capital in the territories and the organizational capacity of social actors.

Keywords: Geographical indications. Territorial development. Social capital. 